\title{
Reproductive phenology, seed removal and early regeneration in relation to distance from parental plants of a native palm in small Atlantic forest fragments
}

\author{
Vanessa Mariano ${ }^{1 *}$ and Alexander V. Christianini ${ }^{1,2}$
}

Received: November 18, 2015

Accepted: February 11, 2016

\begin{abstract}
The Brazilian Atlantic Forest is a global biodiversity hotspot, but most of what remains are small fragments. Small fragments are often harsh environments for forest plant recruitment due to edge effects and the loss of frugivorous animals that provide seed dispersal. We recorded the one-year reproductive phenology of the keystone palm Syagrus romanzoffiana in small $(<2.5 \mathrm{ha})$ Atlantic Forest fragments in southeastern Brazil. We tested the Janzen-Connell hypothesis with seed-removal experiments and followed the five-year survival of recruits in relation to the distance from parental plants. Palms produced many fruits throughout the year (mean 2,600/plant). More seedlings were found away from parental plants than near them, thereby supporting the Janzen-Connell hypothesis. Almost $45 \%$ of seedlings alive in 2010 were dead five years later, but recruitment of new seedlings compensated for this mortality. Distance-dependent factors influenced the density of early ontogenetic stages, but had limited effects on juveniles or on seed removal. High seed production, seed dispersal provided by disturbance-tolerant frugivores and the relatively long-term survival of adults, seedlings and juveniles seem to allow the persistence of $S$. romanzoffiana in the forest fragments, but possibly at the cost of an increased clumped distribution and reduced gene flow at the landscape scale.
\end{abstract}

Keywords: Brazilian Atlantic Forest, crop size, habitat fragmentation, Janzen-Connell hypothesis, large seeds, palms, seed dispersal, seed predation, seedling survival, Syagrus romanzoffiana

\section{Introduction}

The Brazilian Atlantic Forest is considered a hotspot of biodiversity with high levels of endemism (Myers et al. 2000). This biome originally covered an area of 1.5 million $\mathrm{km}^{2}$ along eastern Brazil, but an extensive habitat loss and fragmentation reduced forest cover to about $11 \%-16 \%$, with $80 \%$ of the remnants smaller than 50 ha (Ribeiro et al. 2009). Small fragments are under an increasing influence of edge effects that change microclimate conditions and affect the plant community, especially the early stages of regeneration (Tabarelli et al. 2010 and references therein). Habitat fragmentation also increases the accessibility of hunters to the remnants. Habitat loss, fragmentation and hunting interact synergistically contributing to decrease the abundance of many vertebrate frugivores and seed dispersers, with large animals being more susceptible to local extinctions (Peres \& Palacios 2007). Plants with large seeds ( $>15 \mathrm{~mm}$ ) are more susceptible to the loss of dispersers because their regeneration is strongly seed-limited (Moles \&

\footnotetext{
${ }^{1}$ Programa de Pós-Graduação em Diversidade Biológica e Conservação, Universidade Federal de São Carlos, 18052-780, Sorocaba, SP, Brazil

${ }^{2}$ Departamento de Ciências Ambientais, Universidade Federal de São Carlos, 18052-780, Sorocaba, SP, Brazil

* Corresponding author: vanessa.mds99@gmail.com
} 
Westoby 2002) and these plants rely heavily on large-bodied animals as seed dispersers (Silva \& Tabarelli 2000; Wright \& Duber 2001; Cordeiro \& Howe 2003; Galetti et al. 2006; 2013; Terborgh et al. 2008). For instance, defaunation of large-gaped frugivorous birds has been pointed out as the main source of rapid evolutionary change in seed size of the palm Euterpe edulis in remnants of the Brazilian Atlantic forest (Galetti et al. 2013). Therefore, large-seeded plants should be more susceptible to reductions in seed dispersal in fragmented and defaunated sites than small-seeded plants.

Seed dispersal is a key process to plant community structure and diversity (Schupp \& Fuentes 1995) and provides the template for plant recruitment and spatial distribution of seedlings, juveniles and saplings (Wang \& Smith 2002; Swamy \& Terborgh 2010). From 70 to 90 percent of tree and shrub species in tropical forests rely on animals to disperse their seeds (Jordano 2000). Therefore, an assessment of how frugivorous animals influence seed dispersal is key to understand plant recruitment and population dynamics (Jordano 2000). Frugivorous animals are often profoundly affected by fruit production and adjust their reproduction and movements in the landscape according to the abundance and seasonality of fruit production (Terborgh 1986; Genini et al. 2009; Morellato et al. 2016). Changes in microclimate conditions and abundance of pollinators driven by habitat fragmentation and edge-effects may alter reproductive plant phenology, with possible consequences on frugivores (e.g., Morellato et al. 2016).

Seed dispersal and predation are in the core of the JanzenConnell hypothesis that explains the high diversity of tree species in tropical forests (Janzen 1970; Connell 1971). This hypothesis considers that the likelihood of seed and seedling survival is negatively correlated with seed density and the distance from parental plants. Many plant pests are host-specific and congregate near dense aggregations of hosts. Most seeds produced usually fall beneath the parental plants or are dispersed at short distances from it (e.g., Swamy et al. 2011). The high density of seeds near parental plants enhances the risk of spread of pathogens and the attraction of specialized seed predators, such as weevil beetles (Wright \& Duber 2001). Even if some seeds survive and germinate they will face high sibling competition and herbivory, all of which increase the mortality of seedlings found in high densities near parental plants (Harms et al. 2000). All those effects generate a low per capita likelihood of recruitment for seeds that fall near the parental plants (Janzen 1970; Connell 1971). On the other hand, seeds carried beyond the parent plant crown by dispersal agents are deposited on the ground at lower densities, and exhibit a decreased risk of mortality. Thus dispersal enhances the per capita likelihood of recruitment (Harms et al. 2000; Hyatt et al. 2003; Swamy et al. 2011; Terborgh 2013). Distanceand density-dependent mechanisms, as those predicted by Janzen-Connell hypothesis, seem to be pervasive in tropical tree communities (Harms et al. 2000; Swamy et al. 2011). However, the role of those processes that influences plant recruitment in small forest fragments is not clear. Some sources of mortality of early stages near parental plants may be relaxed or be compensated by other species. For instance, a higher number of undispersed seeds may accumulate beneath parental plants in fragmented sites in response to a decrease in vertebrate seed dispersers. However, invertebrate seed predators may not be able to compensate the mortality of higher numbers of seeds in fragments, allowing unexpected increases in recruitment near parental plants (Wright \& Duber 2001; Wright 2003; Terborgh 2013). Although the effects of habitat loss and fragmentation on species composition and community structure of plants are reasonably well know (Tabarelli et al. 2010; Laurance et al. 2011), the effects upon interactions with seed predators and dispersers (e.g., Mendes et al. 2015) and the way they could cascade and influence plant recruitment is much less understood (e.g., Galetti et al. 2006; Uriarte et al. 2010).

Palms are typical components of the Brazilian Atlantic Forest, where there are about 45 species, many of them endemic (Henderson et al. 1995). Palms are key species to the maintenance of frugivores because of high fruit production in periods of scarcity of other resources and the consumption by a wide variety of animals (Terborgh 1986; Genini et al. 2009). Several palms from Brazilian Atlantic Forest have suffered the effects of forest fragmentation, selective harvest and loss of seed dispersers (reviewed in Montúfar et al. 2011). However, little is known about recruitment and long-term persistence of these palms in small Atlantic Forest fragments (e.g. Souza \& Martins 2004; Galetti et al. 2006; Portela et al. 2010). Most studies investigating interactions between palms and seed predators or dispersers in fragments make inferences about the delayed consequences of these interactions for plant recruitment but do not include data on latter stages such as seedlings and juveniles (e.g., Fleury \& Galetti 2006; Andreazzi et al. 2012; Meiga \& Christianini 2015; Mendes et al. 2015). Studies that simultaneously include data on latter stages of recruitment, such as seedlings, juveniles and adults are rare (Galetti et al. 2006) but are demographically much more relevant (Wang \& Smith 2002; Bruna et al. 2009).

Here we describe the reproductive phenology of Syagrus romanzoffiana, a large-seeded Atlantic forest palm, and test the Janzen-Connell hypothesis for the regeneration of this species in small ( $<2.5 \mathrm{ha})$ Atlantic forest fragments. We evaluate the spatial dynamics of long-term (five year) survival of seedlings and juveniles in relation to distance from parental plants.

\section{Materials and Methods}

\section{Study site}

This study was carried out from July 2010 to October 2015 in Universidade Federal de São Carlos, southeast Brazil 


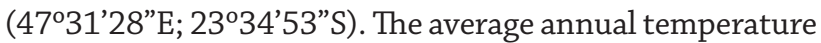
and rainfall are $22^{\circ} \mathrm{C}$ and $1490 \mathrm{~mm}$, respectively (CBA 2006). The vegetation in our landscape is comprised by a transitional ecotone between evergreen and seasonally dry forests, and savanna-like (Cerrado) vegetation (Corrêa et al. 2014; Kortz et al. 2014). The region has a long history of habitat disturbance and is heavily fragmented with $83 \%$ of the remnants in the watershed smaller than 20 ha (Kronka et al. 2005). The study site has five small patches (up to 2.4 ha) of secondary semideciduous Atlantic Forest fragments isolated from each other by a matrix of pastureland and dirty roads. Although we do not have data on abiotic variables at different distances from the border of fragments it is likely that edge effects are pervasive due to the small size of patches and their irregular shape. Most area of the fragments are secondary forests at least 60 years old, based on aerial photographs from 1962 (Corrêa et al. 2014). Myrtaceae and Fabaceae are the most common families in those fragments and lianas are also abundant. Some plant species from Cerrado are found in the pasturelands (Kortz et al. 2014). Details about the floristics of the study site can be found in Kortz et al. (2014). The study site is deprived of most species of large-body seed-dispersing frugivorous animals. Tegu lizards Salvator merianae (Duméryl \& Bibron, 1839) are ocasionaly seem, as well as the Crab-eating Fox Cerdocyon thous Linnaeus, 1766. and the Rusty-margined Guan Penelope superciliaris Temminck, 1815, the largest mammal and bird dispersers of Syagrus romanzoffiana that can still be found in the area (A.V. Christianini unpubl. res.).

\section{Plant species}

Syagrus romanzoffiana (Cham.) Glassman (Arecaceae) is a large-seeded palm that reaches 10 to 15 meters height (Lorenzi 2002; Bernacci et al. 2008) and has a wide distribution in South America from northeastern Brazil to Argentina (Henderson et al. 1995). Mature fruits have a fibrous and fleshy orange mesocarp and only one seed (Lorenzi 2002). The seeds have on average $20.3 \mathrm{~mm}$ long, $11.6 \mathrm{~mm}$ wide and $1.1 \mathrm{~g}$ in weight based on $\mathrm{N}=50$ seeds measured. Fruits of $S$. romanzoffiana are consumed by many frugivores including at least 60 species of insects and vertebrates including small rodents, squirrels, agoutis, pacas, marsupials, coatis, peccaries, tapirs, monkeys, as well as Tegu lizards and birds such as guans (Galetti et al. 1992; Genini et al. 2009; Silva et al. 2011; Sica et al. 2014; Mendes et al. 2015). In contrast to frugivores few species are able to prey on the seed, which is protected by a thick endocarp. Seed predators include beetle larvae (especially Revena rubiginosa (Boheman, 1836), Curculionidae) and squirrels (Guerlinguetus ingrami (Thomas, 1901), Sciuridae) (Galetti et al. 1992; Fleury \& Galetti 2006; Freire et al. 2013; Mendes et al. 2015).

\section{Plant phenology}

To evaluate plant phenology we marked a total of 16 adult $S$. romanzoffiana individuals distributed in the five forest fragments. Only reproductive plants that allow good visibility of the crown at distance were chosen for sampling. Every month, from September 2010 to September 2011, we recorded the number of bunches with inflorescences, unripe or ripe fruits in the marked individuals. Fruit production per plant was estimated based on the mean number of fruits produced per bunch (800 fruits) reported in Galetti et al. (1992) times the number of reproductive bunches with unripe fruits produced per plant in a year.

\section{Distribution and survival of seedlings and juveniles}

To assess the spatial dynamics of seedlings and juveniles we marked all $S$. romanzoffiana at these stages found in five transects $(0.5 \times 20 \mathrm{~m})$, each one departing from the base of five adult palms in a random direction. Palms were at least $60 \mathrm{~m}$ away from another reproductive palm. The closer adult was considered the parental plant. Transects were located in three fragments with $0.1,1.9$ and 2.4 ha, which were distant 75 to $270 \mathrm{~m}$ from each other. Seedling and juvenile stages were classified according Bernacci et al. (2008). Briefly, seedlings were individuals with narrow entire leafs, while juveniles were those with leaves $\geq 2 \mathrm{~cm}$ width or with segmented leaves. Each individual was labeled with a numbered plastic tag. To assess the long term survival, three censuses were conducted in each transect with an interval of one and five years from the first sampling (July 2010, July 2011 and October 2015), representing cohorts 1, 2 and 3, respectively. To evaluate the influence of the distance from the parental plants on seedling and juvenile distribution and survival, we divided the records into two broad categories: near to the parent plants - up to 3 meters away from palm trunk and under the influence of the adult canopy, or far from the parental plant - between 3.1 and $20 \mathrm{~m}$ from palm trunk.

\section{Seed removal experiments}

To evaluate if the survival of dispersed seeds varies with distance from parental plants and test the Janzen-Connell hypothesis, we carried out seed removal experiments during the $S$. romanzoffiana fruiting period. Seeds were obtained from ripe fruits fallen to the ground. We selected seeds with no signs of predation or infection by weevils and the fruit pulp was manually removed. Seeds were marked with a small dot of enamel paint (Testors, Rockford, USA), allowing us to distinguish seeds used in the experiment from naturally fallen ones. We placed a group of five seeds on the ground under five parent plant canopies and another five seeds 20 $\mathrm{m}$ away. Seeds were monitored during 6 months at regular 
intervals of 15 days (September 2010 to March 2011). We recorded the number of seeds germinated, preyed on or removed (which were not found in a $30 \mathrm{~cm}$ radius). To evaluate the fate of removed seeds we carried out another removal experiment (May 2012) beneath five adults. We placed five seeds without fruit pulp beneath the canopy of five reproductive palms. Seeds were individually attached to polyamide threads with a red ribbon at the other end to facilitate their recovery in the field. After seven days we did a search for marked seeds in a $10 \mathrm{~m}$ radius.

\section{Data analysis}

To test the Janzen-Connell hypothesis and evaluate the relationships between densities of seedlings and juveniles in cohorts 1 and 3 and the categories of distances from parental plants we used a repeated-measures ANOVA. Plant stage (seedling or juvenile), distance from parental plant (near or far) were treated as fixed factors, and cohort 1 and 3 as the repeated-measure dependent variable. Residuals were checked for normality and homocedasticity. To assess the relation between seedling and juvenile mortality and the proportion of recruits that changed its ontogenetic stage we performed one-way ANOVAs. To evaluate the relation between distance from parental plants and number of seeds preyed on or removed we performed one-way ANOVA.

\section{Results}

\section{Plant phenology}

Plants bear reproductive bunches during the whole year, with peaks of flowering from September to March and unripe fruits from September to April (Fig. 1). A few bunches with ripe fruits were found every month, with the exception of November, December and February (Fig. 1). Each palm bear up to five bunches at a time. An adult plant produced annually $2.8 \pm 1.2$ inflorescences (mean \pm SD), $3.2 \pm 1.9$ unripe infructescenses and $1.0 \pm 0.8$ ripe infructescenses. A palm was able to produce a mean of nearly 2,600 seeds/year (considering the mean number of bunches with unripe fruits produced by each plant annually). No adult palm died in five years.

\section{Distribution and survival of seedlings and juveniles}

The cohort 1 (July 2010) consisted of 32 seedlings and 38 juveniles of $S$. romanzoffiana, representing a density of 1.40 early plants $/ \mathrm{m}^{2}$. Cohort 2 (July 2011) consisted of 30 seedlings and 38 juveniles, with a density of 1.36 plants $/ \mathrm{m}^{2}$. Two seedlings died and there was no recruitment of new seedlings between cohort 1 and 2. The cohort 3 (September 2015) had 31 seedlings and 35 juveniles, in a total of 1.32 plants $/ \mathrm{m}^{2}$. A recruitment of 21 new seedlings occurred in

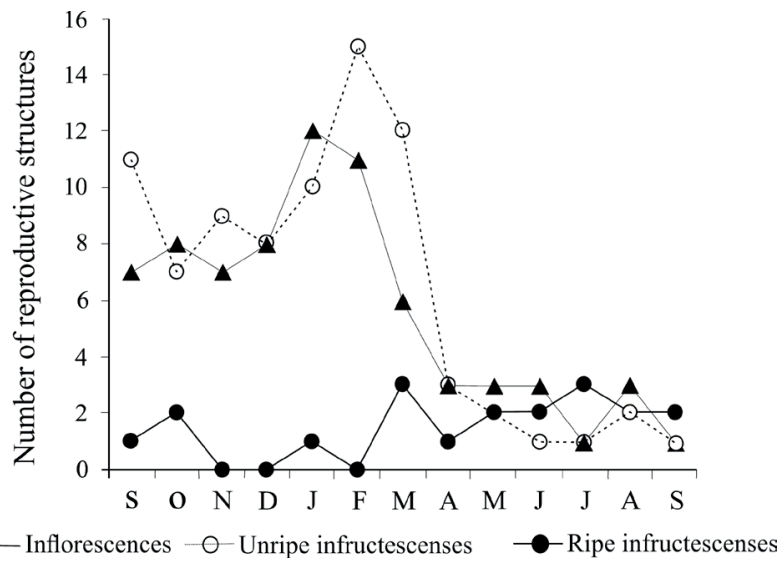

Figure 1. Reproductive phenology of Syagrus romanzoffiana in small Atlantic forest fragments in southeastern Brazil. Total number of inflorescences (solid lines and triangles), unripe (dashed line and white circle) and ripe infructescenses (solid line and black circle) produced by 16 adult palms from September 2010 to September 2011.

the five-year period between cohort 1 and 3 . In general, there were more seedlings far from parents than near, but juveniles were relatively well distributed at both distances (Tab. 1; Fig. 2). These effects were consistent between cohorts 1 and 3 (Tab. 1). There was no interaction between cohort and stage or cohort and distance from parental plants (Tab. 1). There was a mortality of 17 seedlings and 14 juveniles from cohort 1 to 3 (44.3\% of total; Fig. 3). During this five-year period 15 recruits changed its ontogenetic stage. This represented $33.3 \% \pm 27 \%$ and $14.3 \% \pm 3.8 \%$ (mean $\pm \mathrm{SD}$ ) of the total number of survivors recruiting near and far from parental plants, respectively. There was no effect of distance from parental plants on seedling $\left(\mathrm{F}_{1,7}=\right.$ 0.05 ; $=0.83$; Fig. 3$)$ or juvenile mortality $\left(\mathrm{F}_{1,18}=3.7 ; \mathrm{p}=\right.$ 0.09; Fig. 3). Distance from parental plants had no effect on number of recruits that changed its ontogenetic stage after five years $\left(\mathrm{F}_{1,8}=3.70 ; \mathrm{p}=0.09\right)$.

Table 1. Repeated-measures analysis of variance for the effects of plant stage (seedling or juvenile) and distance from parent tree (near or far) on the density of plants of Syagrus romanzoffiana in small Atlantic forest fragments over a five year period (cohort 1 and 3 measured in 2010 and 2015 respectively). See text for details.

\begin{tabular}{|c|c|c|c|c|}
\hline Source & df & MS & $\mathbf{F}$ & $p$ \\
\hline Stage & 1 & 2.741 & 5.807 & 0.028 \\
\hline Distance & 1 & 0.518 & 1.097 & 0.311 \\
\hline Stage ${ }^{\star D i s t a n c e}$ & 1 & 6.521 & 13.816 & 0.002 \\
\hline Error & 16 & 0.471 & & \\
\hline Cohort & 1 & 0.003 & 0.0035 & 0.954 \\
\hline Cohort*Stage & 1 & 0.0223 & 0.023 & 0.881 \\
\hline Cohort*Distance & 1 & 0.618 & 0.631 & 0.439 \\
\hline Cohort ${ }^{\star}$ Stage ${ }^{\star}$ Distance & 1 & 0.481 & 0.492 & 0.493 \\
\hline Error & 16 & 0.979 & & \\
\hline
\end{tabular}



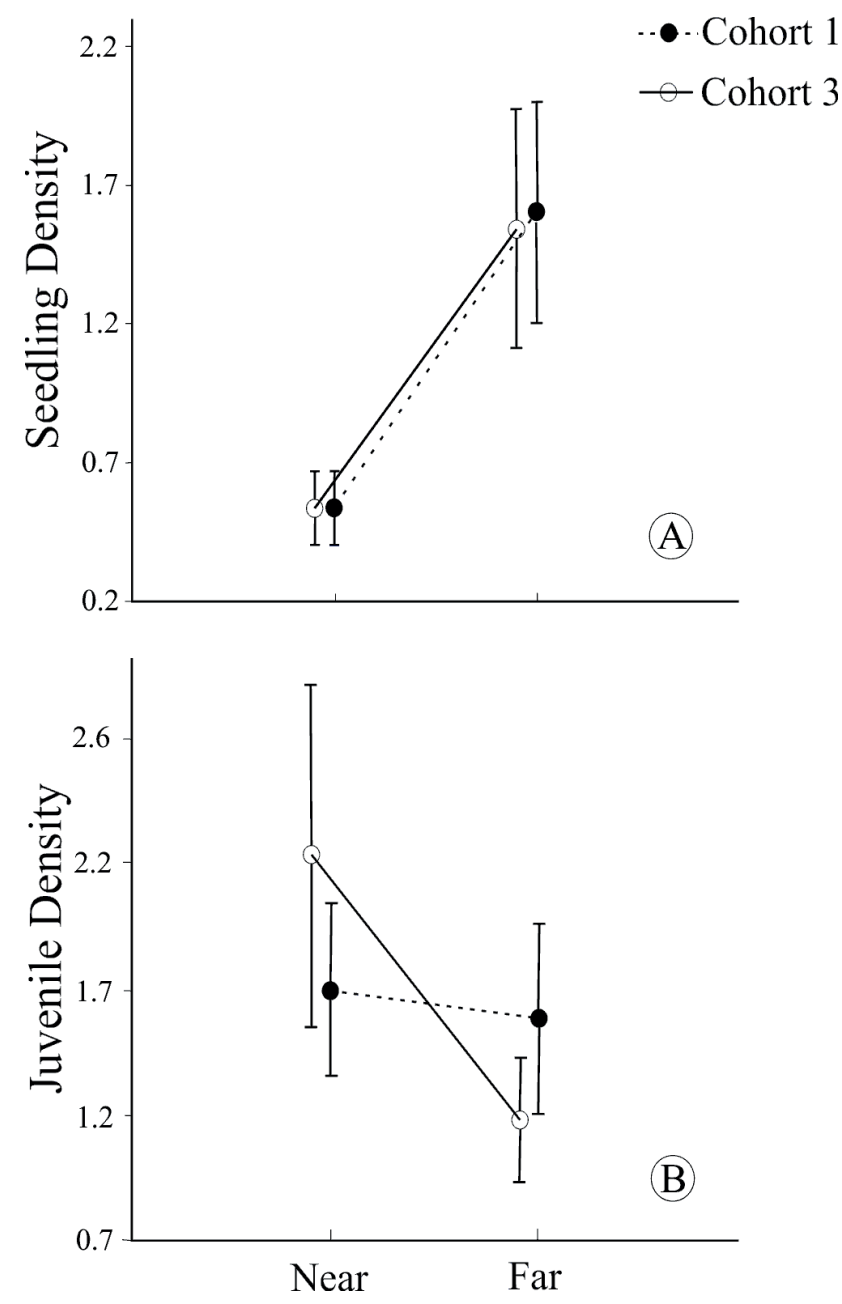

Figure 2. Seedling and juvenile spatial distribution according to the distance from parental plants of Syagrus romanzoffiana in small Atlantic forest fragments. Densities of seedlings (A) and juveniles (B) found near (up to $3 \mathrm{~m}$ away) and far (between 3 and $20 \mathrm{~m}$ away) from parental plants. Data are means \pm SE of the number of individuals $/ \mathrm{m}^{2}$. Densities are presented for cohort 1 (sampled in 2010, black circles) and 3 (sampled in 2015, white circles).

\section{Seed removal experiments}

After six months, 24 seeds (48\%) were preyed on or removed from experiments representing $1.64 \pm 1.9$ seeds (mean \pm SD) near and $1.18 \pm 1.29$ far from parental plants. Therefore, there was no effect of distance from parental plants on seed removal $\left(\mathrm{F}_{1,8}=0.4 ; \mathrm{p}=0.55\right)$. No seed germinated during this period. Considering the removal experiment with seeds attached to threads, $20 \%$ of them were found away partially buried or on the surface with the thread still attached after a week, and thus could be considered dispersed away ( $1 \pm 0.9$ seeds; mean $\pm S D ; N=5)$

\section{Discussion}

Syagrus romanzoffiana produces fruits and seeds during

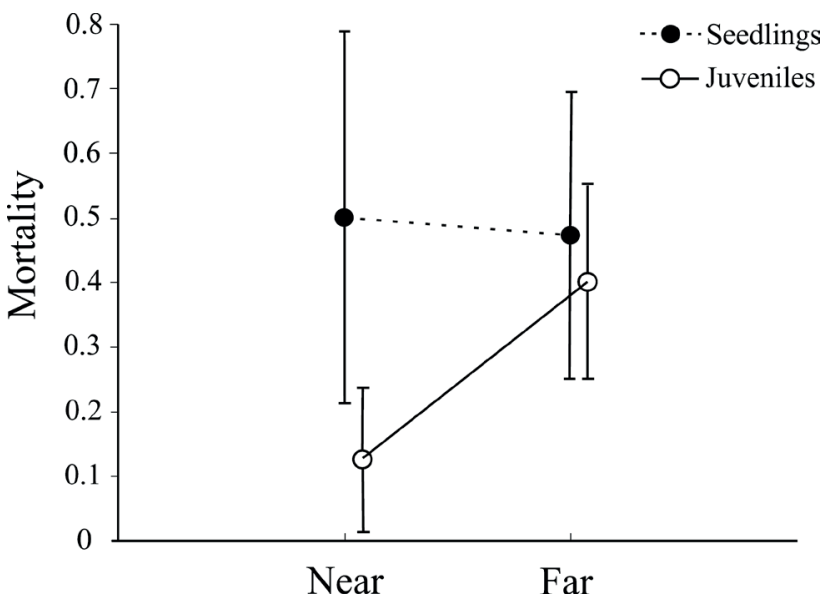

Figure 3. Five-year mortality of seedlings and juveniles of Syagrus romanzoffiana according to the distance from parental plants in small Atlantic forest fragments. Mean $( \pm$ SE) proportion of seedlings (black circles) and juveniles (white circles) that died in the period between cohorts 1 (sampled in July 2010) and 3 (sampled in October 2015).

the whole year (see also Genini et al. 2009; Liebsch \& Mikich 2009; Freire et al. 2013) offering fruits during the winter, which is the usual period of scarcity of fleshy fruits (see Morellato et al. 2000; Genini et al. 2009). This highlights the potential role of this palm as a keystone resource for frugivores in small Atlantic forest fragments (Silva et al. 2011). Each palm produces a high number of fruits/seeds per year (2,600 seeds). There is evidence that forest palms, such as Attalea speciosa and A. humilis, invest more resources to reproduction whenever exposed to the high light conditions found in disturbed tracts of forests near edges (Barot et al. 2005; Andreazzi et al. 2012). High seed production may satiate seed predators enhancing the chances of per capita seed survival (Wright \& Duber 2001; Andreazzi et al. 2012; Meiga \& Christianini 2015). Predator satiation and high adult survival (no death in five years) may allow the longterm persistence of palm populations in disturbed Atlantic forest fragments, as suggested by detailed long-term studies working with other Atlantic forest palms (Souza \& Martins 2004; Portela et al. 2010).

Although it is common to find many seeds of $S$. romanzoffiana accumulated beneath parental palms (V. Mariano unpubl. res.), seedling densities increase with distance from parental plants, indicating that distanceand density-dependent processes may affect recruitment in this early stage like expected from the Janzen-Connell model. This supports the importance of seed dispersal for recruitment at this early stage (Hyatt et al. 2003; Swamy et al. 2011). However, the density of later stages is not affected by distance from parental plants up to $20 \mathrm{~m}$, suggesting that mortality related to distance from parents affect especially early stages at this spatial scale. Smaller plants, such as seedlings, are usually more susceptible to environmental stressors (shade, herbivory) than larger plants, such as juveniles (Moles \& Westoby 2004). Seedlings and juveniles 
may also have different requirements of light and humidity, which vary at small scales. A good spot for a seedling may be a bad spot for a juvenile creating stage-related spatial mismatch in recruitment (Schupp 1995). After five years the mortality of early stages was virtually compensated by recruitment of new seedlings and transitions to the next ontogenetic stage. More than $60 \%$ of the plants that survived did not change its ontogenetic stage, suggesting a slow development (Bernacci et al. 2008) and a longterm persistence of seedlings and juveniles in the small fragments. A demographic approach with data on juvenile to sapling and adult transitions is needed to confirm if the repeated recruitment of seedlings and long-term persistence of juveniles is enough to allow adult recruitment in the fragments (Bruna et al. 2009; Portela et al. 2010).

It is known that medium and small-sized forest fragments presented biotic and abiotic conditions that affect $S$. romanzoffiana seed predation in idiosyncratic ways (Fleury \& Galetti 2006; Mendes et al. 2015). Defaunation and habitat disturbances can synergistically affect seed predation, dispersal and/or recruitment of large-seeded palms such as Astrocaryum aculeatissium (Galetti et al. 2006) and Attalea dubia (Meiga \& Christianini 2015) in Atlantic forests. However, some seed predators, such as squirrels, may occasionally act as seed dispersers allowing a certain degree of seed distribution (Terborgh 2013). The squirrel Guerlinguetus ingrami is an important seed predator and possibly disperser of S. romanzoffiana (Paschoal \& Galetti 1995; Bordignon et al. 1996; Fleury \& Galetti 2006; Freire et al. 2013; Mendes et al. 2015). In spite seed predation by squirrels is not reported in other Atlantic forest fragments smaller than 10 ha (Fleury \& Galetti 2006; Freire et al. 2013) our small fragments are not very distant apart from each other which allow movements of squirrels among some of them (V. Mariano \& A.V. Christianini unpubl. res.). Large-bodied frugivores such as tapirs behave as main seed dispersers of $S$. romanzoffiana in more pristine habitats (Sica et al. 2014) but are extinct in our site. However, other animals that still persist in the region like squirrels, Crabeating fox Cerdocyon thous, Guans Penelope superciliaris, and Tegu lizards Salvator teguixin may provide some seed dispersal (Mendes et al. 2015; A.V. Christianini unpubl. res.). Our results suggest that even this vestigial dispersal can be important to allow early palm regeneration in small fragments, distributing seeds some distances away in the absence of major dispersers.

The Janzen-Connell hypothesis is supported by several studies (see reviews in Hyatt et al. 2003; Terborgh 2013) but it is still poorly investigated in Atlantic forests (e.g., Pizo 1997; Pinto et al. 2009). In small forest fragments, distance-dependent factors seem to influence the density of early ontogenetic stages of $S$. romanzoffiana, but with a limited effect on juveniles. The high seed production, some seed dispersal provided by disturbance-tolerant species and the relatively long-term survival of seedlings, juveniles and adults are probably allowing the persistence of the largeseeded $S$. romanzoffiana in our fragments. This does not mean that $S$. romanzoffiana is free from negative effects produced by habitat fragmentation. We have no information about the genetic structure of $S$. romanzoffiana, but data on one of the most common local trees, the bird-dispersed legume Copaifera langsdorffii, is available (Martins et al. 2016). In the study sites $C$. langsdorffii has abundant seedlings and saplings and its regeneration is not influenced by the proximity to edges or distance- and density-dependent effects (Martins et al. 2016). However, genetic analyses at landscape scale have revealed a decrease in genetic diversity of seedlings compared to adults (Martins et al. 2016) in line with theoretical expectations of habitat fragmentation (Young et al. 1996). The loss of genetic diversity is compatible with restricted seed dispersal and increased recruitment near parental plants (Martins et al. 2016). Restricted dispersal is also expected to produce increasing levels of clumped spatial distribution (Souza \& Martins 2004; Sica et al. 2014) potentially enhancing distance- and densitydependent effects that decrease seedling density and survival, as demonstrated here.

\section{Acknowledgements}

We thank Universidade Federal de São Carlos - campus Sorocaba for institutional and technical support. We also thank two anonymous reviewers for helpful comments on an earlier version of the manuscript. This work was supported by a scholarship to Vanessa Mariano from PIBIC/ CNPq (Conselho Nacional de Desenvolvimento Científico e Tecnológico).

\section{References}

Andreazzi CS, Pimenta CS, Pires AS, Fernandez FAZ, Oliveira-Santos LG, Menezes JFS. 2012. Increased productivity and reduced seed predation favor a large-seeded palm in small Atlantic Forest fragments. Biotropica 44: 237-245.

Barot S, Mitja D, Miranda I, Meija GD, Grimaldi M. 2005. Reproductive plasticity in an Amazonian palm. Evolutionary Ecology Research 7: 1051-1065.

Bernacci LC, Martins FR, Santos FAM. 2008. Estrutura de estádios ontogenéticos em população nativa da palmeira Syagrus romanzoffiana (Cham.) Glassman (Arecaceae). Acta Botanica Brasilica 22: 119-130.

Bordignon M, Margarido TCC, Lange RR. 1996. Formas de abertura dos frutos de Syagrus romanzoffiana (Chamisso) Glassman efetuadas por Sciurus ingrami Thomas (Rodentia, Sciuridae). Revista Brasileira de Zoologia 13: 812-828.

Bruna EM, Fiske IJ, Trager MD. 2009. Habitat fragmentation and plant populations: is what we know demographically irrelevant? Journal of Vegetation Science 20: 569-576.

CBA - Companhia Brasileira de Alumínio. 2006. Dados de vazão e precipitação. Relatório Técnico: Estação Meteorológica Represa de Itupararanga, Votorantim (SP).

Connell JH. 1971. On the role of natural enemies in preventing competitive exclusion in some marine animals and in rain forest trees. In: Boer PJ, Gradwell G. (eds.) Dynamics of Populations. Wageningen, PUDOC. p. 298-312. 
Cordeiro NJ, Howe HF. 2003. Forest fragmentation severs mutualism between seed dispersers and an endemic African tree. Proceedings of the National Academy of Sciences 100: 14052-14056.

Corrêa LS, Cardoso-Leite E, Castello ACD, et al. 2014. Estrutura, composição florística e caracterização sucessional em remanescente de floresta estacional semidecidual no sudeste do Brasil. Revista Árvore 38: 799809.Fleury M, Galetti M. 2006. Forest fragment size and microhabitat effects on palm seed predation. Biological Conservation 131: 1-13.

Freire CDE, Closel MB, Hasui E, Ramos FN. 2013. Reproductive phenology, seed dispersal and seed predation in Syagrus romanzoffiana in a highly fragmented landscape. Annales Botanici Fennici 50: 220-228.

Galetti M, Paschoal M, Pedroni F. 1992. Predation on palm nuts (Syagrus romanzoffiana) by squirrels (Sciurus ingrami) in south-east Brazil. Journal of Tropical Ecology 8: 121-123.

Galetti M, Donatti CI, Pires AS, Guimarães Jr. PR, Jordano P. 2006. Seed survival and dispersal of an endemic Atlantic forest palm: the combined effects of defaunation and forest fragmentation. Botanical Journal of the Linnean Society 151: 141-149.

Galetti M, Guevara R, Côrtes MC, et al. 2013. Functional extinction of birds drives rapid evolutionary changes in seed size. Science 340: 1086-1090.

Genini J, Galetti M, Morellato LPC. 2009. Fruiting phenology of palms and trees in an Atlantic rainforest land-bridge island. Flora 204: 131-145.

Harms KE, Wright SJ, Calderón O, Hernández A, Herre EA. 2000. Pervasive density-dependent recruitment enhances seedling diversity in a tropical forest. Nature 404: 493-495.

Henderson A, Galeano G, Bernal R. 1995. Field guide to the palms of the Americas. Princeton, Princeton University Press.

Hyatt LA, Rosenberg MS, Howard TG, et al. 2003. The distance dependence prediction of the Janzen-Connell hypothesis: a meta-analysis. Oikos 103: 590-602.

Janzen DH. 1970. Herbivores and the number of tree species in tropical forests. The American Naturalist 104: 501-528.

Jordano P. 2000. Fruits and frugivory. In: Fenner M. (ed.) Seeds: the ecology of regeneration in plant communities. 2nd. edn. Wallingford, CAB International. p. 125-165.

Kortz AR, Coelho S, Castello ACD, Corrêa LS, Leite EC, Koch I. 2014. Wood vegetation in Atlantic rain forest remnants in Sorocaba (São Paulo, Brazil). Check List 10: 344-354.

Kronka FJN, Nalon MA, Matsukuma CK, et al. 2005. Inventário Florestal da Vegetação Natural do Estado de São Paulo. São Paulo, Imprensa Oficial.

Laurance WF, Camargo JLC, Luizão RCC et al. 2011. The fate of Amazonian forest fragments: A 32-year investigation. Biological Conservation 144: 56-67.

Liebsch D, Mikich SB. 2009. Fenologia reprodutiva de espécies vegetais da Floresta Ombrófila Mista do Paraná, Brasil. Brazilian Journal of Botany 32: 375-391.

Lorenzi H. 2002. Árvores brasileiras: Manual de identificação e cultivo de plantas arbóreas nativas do Brasil. Vol. I. Nova Odessa, Editora Plantarum.

Martins K, Kimura RK, Francisconi AF, Gezan S, Kainer K, Christianini AV. 2016. The role of very small fragments in conserving genetic diversity of a common tree in a hyper fragmented Brazilian Atlantic forest landscape. Conservation Genetics (in press). doi: 10.1007/ s10592-015-0800-7

Meiga AYY, Christianini AV. 2015. Changes in seed predation of Attalea dubia in a gradient of Atlantic Forest disturbance in Brazil. Palms 59: 135-144.

Mendes CP, Ribeiro MC, Galetti M. 2015. Patch size, shape and edge distance influence seed predation on a palm species in the Atlantic forest. Ecography 38: 1-11.

Moles AT, Westoby M. 2002. Seed addition experiments are more likely to increase recruitment in large-seeded species. Oikos 99: 241-248.

Moles AT, Westoby M. 2004. What do seedlings die from and what are the implications for the evolution of seed size? Oikos 106: 193-199.

Montúfar R, Anthelme F, Pintaud JC, Balslev H. 2011. Disturbance and resilience in tropical American palm populations and communities. Botanical Review 77: 426-461.

Morellato LPC, Talora DC, Takahasi A, Bencke CC, Romera EC, Zipparro VB. 2000. Phenology of Atlantic Rain Forest trees: a comparative study. Biotropica 32: 811-823.
Morellato LPC, Alberton B, Alvarado ST, et al. 2016. Linking plant phenology to conservation biology. Biological Conservation 195: 60-72.

Myers N, Mittermeier RA, Mittermeier CG, Fonseca GAB, Kent J. 2000. Biodiversity hotspots for conservation priorities. Nature 403: 853-858.

Paschoal M, Galetti M. 1995. Seasonal food use by the neotropical squirrel Sciurus ingrami in southeastern Brazil. Biotropica 27: 268-273.

Peres CA, Palacios E. 2007. Basin-wide effects of game harvest on vertebrate population densities in Amazonian forests: implications for animalmediated seed dispersal. Biotropica 39: 304-315.

Pinto SRR, Santos AMM, Tabarelli M. 2009. Seed predation by rodents and safe sites for large-seeded trees in a fragment of the Brazilian Atlantic Forest. Brazilian Journal of Biology 69: 763-771.

Pizo MA. 1997. Seed dispersal and predation in two populations of Cabralea canjerana (Meliaceae) in the Atlantic Forest of southeastern Brazil. Journal of Tropical Ecology 13:559-578.

Portela RCQ, Bruna E, Santos FAM. 2010. Demography of palm species in Brazil's Atlantic forest: a comparison of harvested and unharvested species using matrix models. Biodiversity and Conservation 19: 2389-2403.

Ribeiro MC, Metzger JP, Martensen, AC, Ponzoni FJ, Hirota MM. 2009. Brazilian Atlantic forest: how much is left and how is the remaining forest distributed? Implications for conservation. Biological Conservation 142:1141-1153.

Schupp EW. 1995. Seed-seedling conflicts, habitat choice and patterns of plant recruitment. American Journal of Botany 82: 399-409.

Schupp EW, Fuentes M. 1995. Spatial patterns of seed dispersal and the unification of plant population ecology. Ecoscience 2: 267-275.

Sica YV, Bravo SP, Giombini MI. 2014. Spatial pattern of Pindó palm (Syagrus romanzoffiana) recruitment in Argentinian Atlantic forest: the importance of Tapir and effects of defaunation. Biotropica 46: 696-703.

Silva FR, Begnini RM, Lopes BC, Castellani TT. 2011. Seed dispersal and predation in the palm Syagrus romanzoffiana on two islands with different faunal richness, southern Brazil. Studies on Neotropical Fauna and Environment 46: 163-171.

Silva JMC, Tabarelli M. 2000. Tree species impoverishment and the future flora of the Atlantic forest of northeast Brazil. Nature 404: 72-74.

Souza AF, Martins FR. 2004. Population structure and dynamics of a neotropical palm in fire-impacted fragments of the Brazilian Atlantic forest. Biodiversity and Conservation. 13: 1611-1632.

Swamy V, Terborgh J. 2010. Distance-responsive natural enemies strongly influence seedling establishment patterns of multiple species in an Amazonian rain forest. Journal of Ecology 98: 1096-1107.

Swamy V, Terborgh J, Dexter KG, Best BD, Alvarez P, Cornejo F. 2011. Are all seeds equal? Spatially explicit comparisons of seed fall and sapling recruitment in tropical forest. Ecology Letters 14: 195-201.

Tabarelli M, Aguiar AV, Ribeiro MC, Metzger JP, Peres CA. 2010. Prospects for biodiversity conservation in the Atlantic forest: Lessons from aging human-modified landscapes. Biological Conservation 143: 2328-2340.

Terborgh, J. 1986. Keystone plant resources in the tropical forest. In: Soule M. (ed.) Conservation biology: the science of scarcity and diversity. Sunderland, Sinauer Associates. p. 330-344.

Terborgh J. 2013. Using Janzen-Connell to predict the consequences of defaunation and other disturbances in tropical forests. Biological Conservation 163: 7-12.

Terborgh J, Nuñez-Iturri G, Pitman NCA, et al. 2008. Tree recruitment in an empty forest. Ecology 89: 1757-1768.

Uriarte M, Bruna EM, Rubim P, Anciães M, Jonckheere I. 2010. Effects of forest fragmentation on the seedling recruitment of a tropical herb: assessing seed vs. safe-site limitation. Ecology 91: 1317-1328.

Wang BC, Smith TB. 2002. Closing the seed dispersal loop. Trends in Ecology \& Evolution 17: 379-385.

Wright SJ. 2003. The myriad consequences of hunting for vertebrates and plants in tropical forests. Perspectives in Plant Ecology, Evolution and Systematics 6: 73-86.

Wright SJ, Duber HC. 2001. Poachers and forest fragmentation alter seed dispersal, seed survival, and seedling recruitment in the palm Attalea butyraceae, with implications for tropical tree diversity. Biotropica 39: 363-371.

Young A, Boyle T, Brown T. 1996. The population genetic consequences of habitat fragmentation for plants. Trends in Ecology and Evolution 11: $413-418$ 